\title{
HUBUNGAN WAKTU TUNGGU PENDAFTARAN DENGAN KEPUASAN PASIEN DI TEMPAT PENDAFTARAN PASIEN RAWAT JALAN (TPPRJ)
}

\author{
Marice Simarmata ${ }^{1}$, Balqis Wasliati ${ }^{2}$, Felix Kasim ${ }^{2}$, Ira Cahyani \\ Saragih ${ }^{2}$ \\ Institut Kesehatan Medistra Lubuk Pakam \\ Jl. Sudirman No.38 Lubuk Pakam Kec. Lubuk Pakam Kab. Deli Serdang, \\ Sumatera Utara \\ Email: maricesimarmata@medistra.ac.id
}

DOI $10.35451 / j k g . v 3 i 2.695$

\begin{abstract}
Patient waiting time in service at Place Of Patient Outpatient Registration was one of the important factors that will determine the hospital's initial image. Patient waited time also becomes one of the potential components as the cause of dissatisfaction. If the waiting time in the old outpatient medical record then it will reduce patient comfort. This research aims to registration waiting time relationship with patient satisfaction in Outpatient Registration Place Grandmed of Hospital Lubukpakam 2017. In this paper type was observational cross-sectional study. The population in this research was the outpatient Outpatient Registration Place (TPPRJ) that 124 people were sampled by purposive sampling techniques, methods of data collection by interviewing indirectly by using a questionnaire, data analysis using Chi-square test. Based on the results of writing, it is known that the waiting time for registration in the fast category is $56.5 \%$. Patient satisfaction in the satisfied category of $62.1 \%)$. There is a registration waiting time relationship with patient satisfaction in Outpatient Registration Place $p$-value (= $0.010)<a(=0.05)$. Suggested for Outpatient Registration Place Officer Grandmed of Hospital Lubuk Pakam, should pay attention to the long waiting time at Outpatient Registration Place to work more quickly and precisely according to the SOP so that the patient always feel satisfied, happy with the services already provided by the clerk.
\end{abstract}

Kata Kunci: Waktu Tunggu Registrasi, Kepuasan Pasien

Keywords: Waiting Time of Registration, Patient Satisfactio 


\section{Pendahuluan}

Menurut Aditama (2011) rumah sakit adalah industri jasa kesehatan dan merupakan pusat pelayanan kesehatan yang menyelenggarakan pelayanan medis dasar dan spesialis baik rawat inap maupun rawat jalan yang menjalankan fungsi dalam manajerialnya.

Untuk menjalankan pelayanan rumah sakit yang bermutu yang merupakan prioritas dalam memberikan pelayanan kesehatan diperlukan aturan manajemen yang baik untuk sumber daya manusianya, sehingga bisa meningkatkan dan menentukan keberhasilan pelayanan di rumah sakit. Jika rumah sakit menjaga mutu pelayanan maka akan memberikan manfaat antara lain peningkatan efektifitas dan efisiensi pelayanan kesehatan, peningkatan kepercayaan masyarakat terhadap pelayanan kesehatan, dan melindungi dari gugatan hukum (Hidayat, 2010). Berdasarkan hal tersebut maka rumah sakit wajib memberikan pelayanan kesehatan yang bermutu disetiap bagian yang ada. Hal ini sesuai dengan hasil penelitian Rachmadi (2010) bahwa $77 \%$ pasien tidak akan kembali kerumah sakit jika tidak mendapatkan pelayanan yang bermutu. Pasien merasa puas jika mendapatkan pelayanan kesehatan yang bermutu misalnya fasilitas rumah sakit yang memadai dan tenaga kesehatan yang ramah. Beberapa keluhan pasien sewaktu di rumah sakit diantaranya pasien tidak memperoleh informasi yang lengkap tentang status kesehatannya dan tenaga kesehatan tidak professional dalam memberikan pelayanan kesehatan, sehingga mengakibatkan pasien berada pada posisi yang lemah sebagai penerima jasa pelayanan kesehatan (Suryawati, 2011). Hal ini sesuai dengan hasil penelitian Nofiana (2011) bahwa ada hubungan antara mutu pendaftaran dengan kepuasan pasien di Rumah Sakit PKU Muhammadiyah Karanganyar.

Sumber ketidakpuasan dengan kesehatan yang sering dirasakan oleh pasien adalah jumlah waktu mereka menunggu selama melakukan kunjungan klinik. Ada sebagian studi yang membuat dokumentasi hubungan waktu tunggu dengan kepuasaan pasien dan hasilnya turun. Hubungan ini telah terdokumentasi dengan baik dalam situasi umum yang melibatkan pasien menunggu (Salimah, 2010).

Waktu tunggu tidak selalu menjadi pengalaman negatif. Waktu tunggu memberikan pengaruh positif bagi evaluasi layanan dan pengalaman tunggu bagi pasien yang merupakan indicator penting dalam kepuasan pasien (Taylor, 2014). Bagian pelayanan kesehatan untuk pendaftaran pasien yang berobat jalan maupun dirawat inap di rumah sakit merupakan tempat pendaftaran pasien rawat jalan (TPPRJ). Pelayanan rawat jalan yaitu gerbang utama dirumah sakit dan memiliki peran yang penting untuk pasien karena memberikan kesan pertama sebagai konsumen (Wahyuningsih, 2010).

Salah satu indikator menentukan citra awal rumah sakit adalah waktu tunggu pasien di TPPRJ karena penyebab ketidakpuasan pasien. Menurut pasien pelayanan kesehatan dikatakan jelek jika sakit pasien tidak sembuh, lama mengantri, dan tenaga kesehatan tidak ramah walaupun kompeten. Bila waktu tunggu di rekam medis rawat jalan lama maka mengurangi kenyamanan 
pasien dan berpengaruh pada citra rumah sakit yang dapat mempengaruhi utilitas pasien di masa mendatang (Febriyanti, 2013)

Berdasarkan hasil survei pendahuluan didapatkan data bahwa jumlah pasien rawat jalan periode Januari sampai dengan November 2016 sebanyak 151.680 orang $(85,513 \%)$. Peneliti melakukan survei pendahuluan di bagian Rekam Medik Rumah Sakit Grandmed Lubuk Pakam, dengan mewawancarai beberapa pegawai rumah sakit dan pasien rawat jalan. Petugas TPPRJ menginformasikan bahwa rata-rata pasien yang mendaftar setiap minggu adalah sekitar 1.032 orang. Selama ini banyak keluhan secara formal maupun informal disampaikan, berhubungan dengan pelayanan kesehatan diantaranya mengenai prosedur administrasi lama karena pasien yang banyak dan jumlah komputer yang terbatas, kurangnya kejelasan informasi yang diberikan dan berbagai pelayanan lain yang kurang memuaskan.

TPPRJ Rumah Sakit Grandmed Lubuk Pakam memiliki peran penting untuk selalu memberikan kepuasan bagi pasien yang mendaftar. Kepuasan pasien tersebut akan berdampak baik bagi stabilitas rumah sakit. Berdasarkan survei pendahuluan yang dilakukan peneliti diketahui bahwa presentase ketidakpuasan pasien masih tinggi. Adapun salah satu penyebabnya adalah lamanya waktu tunggu saat proses pendaftaran yang dikarenakan jumlah komputer yang terbatas. Oleh karena itu, peneliti tertarik menganalisis lebih jauh terhadap hubungan waktu tunggu pendaftaran dengan kepuasan pasien di Tempat Pendaftaran Pasien Rawat Jalan (TPPRJ) di Rumah Sakit Grandmed
Lubuk Pakam Tahun 2017".

\section{METODE PENELITIAN}

Desain penelitian yang digunakan adalah observasional dengan studi cross- sectional.

Populasi pada penelitan ini adalah pasien rawat jalan di Tempat Pendaftaran Pasien Rawat Jalan (TPPRJ) Rumah Sakit Grandmed (RSGM) Lubuk Pakam dan berdasarkan data sekunder didapat bahwa jumlah pasien rawat jalan setiap bulan di Rumah Sakit Grandmed (RSGM) Lubuk Pakam sebanyak 6.737 orang. Besar sampel pada penelitian ini yaitu sebanyak 124 orang. Teknik sampling yang digunakan non probability dengan pendekatan purposive sampling.

\section{HASIL}

Tabel 1 Waktu Tunggu Pendaftaran Pasien

\begin{tabular}{|l|c|c|}
\hline $\begin{array}{c}\text { Kategori } \\
\text { Waktu Tunggu }\end{array}$ & \multicolumn{2}{|c|}{ Jumlah Sampel } \\
\hline & $\mathrm{N}$ & $\%$ \\
\hline Cepat & 70 & 56,5 \\
\hline Lambat & 54 & 43,5 \\
\hline Total & 124 & 100 \\
\hline
\end{tabular}

Hasil penelitian menunjukkan bahwa responden yang mengalami kategori waktu tunggu cepat sebanyak 70 orang $(56,5 \%)$ dan responden yang mengalami kategori waktu tunggu lambat sebanyak 54 orang $(43,5 \%)$. 
Tabel 2 Kepuasan Pasien di Tempat Pendaftaran Pasien Rawat Jalan (TPPRJ)

\begin{tabular}{|l|c|c|}
\hline $\begin{array}{c}\text { Kepuasan } \\
\text { Pasien }\end{array}$ & \multicolumn{2}{|c|}{ Jumlah Sampel } \\
\hline & $\mathrm{N}$ & $\%$ \\
\hline Puas & 77 & 62.1 \\
\hline Tidak Puas & 47 & 37.9 \\
\hline Total & 124 & 100 \\
\hline
\end{tabular}

Tabel 2 diperoleh hasil sebanyak 77 sampel (62.1\%) merasa puas terhadap pelayanan pendaftaran pasien rawat jalan.

\section{PEMBAHASAN}

\section{Kepuasan Pasien Di Tempat Pendaftaran Pasien Rawat Jalan (TPPRJ) di Rumah Sakit Grandmed Lubuk Pakam Tahun 2017}

Dari hasil penelitian bahwa pasien yang puas sebanyak 77 orang $(62,1 \%)$ dan pasien yang tidak puas sebanyak 47 orang (37,9\%). Kepuasan pelanggan ditentukan oleh berbagai jenis pelayanan yang didapatkan selama menggunakan beberapa tahapan pelayanan kesehatan. Ketidakpuasan yang diperoleh pada tahap awal pelayanan menimbulkan persepsi berupa kualitas pelayanan yang buruk untuk tahap selanjutnya, sehingga pelanggan merasa tidak puas dengan pelayanan secara keseluruhan. Kepuasan pelanggan merupakan ujung dalam era persaingan saat ini. Pelayanan yang memuaskan akan membuat pasien setia untuk tetap menggunakan jasa yang diberikan. Pelanggan yang loyal akan membuat institusi pemberi pelayanan kesehatan mampu bertahan (Prastiwi, 2007).

Hal tersebut sesuai dengan pendapat Robbins (2012) yaitu kepuasan konsumen merupakan perbandingan antara harapan yang dimiliki oleh konsumen dengan kenyataan yang diterima oleh konsumen dengan kenyataan yang diterima oleh konsumen dengan kenyataan yang diterima oleh konsumen pada saat mengkonsumsi produk atau jasa. Konsumen yang mengalami kepuasan terhadap suatu produk atau jasa dapat dikategorikan ke dalam konsumen masyarakat, konsumen instansi dan konsumen individu. Dalam penelitian ini peneliti menitikberatkan pada kepuasan pasien. Pasien adalah orang yang karena kelemahan fisik atau mentalnya menyerahkan pengawasan dan perawatannya, menerima dan mengikuti pengobatan yang ditetapkan oleh tenaga kesehatan.

Waktu tunggu tidak dapat dihilangkan sepenuhnya dari usaha layanan jasa. Evaluasi waktu tunggu oleh konsumen dipengaruhi secara negatif oleh persepsi waktu tunggu. Hal yang penting diperhatikan bahwa baik ekspektasi maupun hasil akan mempengaruhi evaluasi pelanggan terhadap waktu. Tingkat ketidakpuasan pelanggan dalam menunggu dapat dikurangi dengan cara mengatur persepsi waktu tunggu pelanggan. Pendekatan lainnya dapat dilakukan dengan cara meningkatkan kepuasan konsumen selama jeda waktu menunggu. Kepuasan waktu tunggu menjadi positif bila waktu tunggu yang sebenarnya lebih pendek daripada batas waktu yang dijanjikan. Informasi tentang waktu tunggu serta panjanganya antrian yang diberikan penyedia jasa memiliki dampak positif pada evaluasi waktu tunggu oleh 
konsumen. Pelanggan akan lebih tidak stres dengan adanya informasi tersebut, khususnya jika lama menunggu lebih dari 10-15 menit (Assauri, 2011).

Unsur kenyamanan meliputi ruang pelayanan yang bersih, ruang tunggu yang bersih dan nyaman, toilet bersih dan area parkir yang luas. Kenyamanan lingkungan merupakan suatu faktor yang berpengaruh terhadap kepuasan pelanggan atas suatu jasa. Keamanan pelayanan merupakan terjaminnya tingkat keamanan lingkungan unit penyelenggara pelayanan ataupun sarana yang digunakan, sehingga masyarakat merasa tenang untuk mendapatkan pelayanan terhadap risiko-risiko yang diakibatkan dari pelaksanaan pelayanan.

Unsur kecepatan pelayanan meliputi petugas menyelesaikan tugasnya dengan cepat, sistem antrian yang ada berjalan dengan cepat dan lancar. Ketepatan jadwal pelayanan adalah kepastian pelaksanaan waktu pelayanan sesuai dengan yang telah ditetapkan. Unsur ketepatan jadwal pelayanan yaitu pelayanan selalu tepat waktu sesuai dengan yang ditetapkan. Kecepatan pelayanan tergantung dari waktu tunggu untuk mendapatkan pelayanan medis dan turut mempengaruhi pengambilan keputusan. Penelitian Suryawan dalam dalam Yunevy (2013) menyimpulkan bahwa baik buruknya pelayanan bagi pasien juga tergantung dari waktu yang diperlukan untuk mendapat pelayanan. Pelayanan kesehatan dipandang baik sebab mereka dapat dilayani dengan cepat tanpa menunggu lama.

Menurut asumsi peneliti bahwa kepuasan pasien sangat dipengaruhi oleh beberapa faktor, faktor yang paling sering dirasakan pasien menjadi penyebab ketidakpuasan adalah waktu tunggu. Persepsi waktu tunggu, kepuasan terhadap informasi yang diberikan saat terjadi keterlambatan, dan kepuasan terhadap lingkungan tunggu. Aspek subyektif dan obyektif waktu tunggu memiliki dampak negatif pada respon kognitif dan afektif pelanggan dalam menunggu. Persepsi waktu tunggu mempengaruhi dimensi kognitif dari penilaian waktu oleh pelanggan.

Pelanggan yang menunggu tidak hanya mengeluarkan biaya secara ekonomi, namun juga memiliki efek psikologis yakni ketidakpastian tentang lamanya waktu tunggu sehingga merasa stres.

\section{Hubungan Waktu Tunggu \\ Pendaftaran Dengan Kepuasan Pasien Di Tempat Pendaftaran Pasien Rawat Jalan (TPPRJ) di Rumah Sakit Grandmed Lubuk Pakam Tahun 2017}

Dari hasil penelitian didapatkan bahwa bahwa sebanyak 70 orang $(100,0 \%)$ responden mengalami waktu tunggu cepat dengan puas dan tidak ada responden yang mengalami waktu tunggu cepat dengan tidak puas. Sebanyak 7 orang $(13,0 \%)$ responden mengalami waktu tunggu lambat dengan puas dan sebanyak 47 orang $(87,0 \%)$ responden yang mengalami waktu tunggu lambat dengan tidak puas. Berdasarkan hasil uji statistik dengan menggunakan uji Chi Squere menunjukan bahwa pValue $(=0.010)<a(=0,05)$. Maka dapat disimpulkan bahwa Ha diterima yaitu ada hubungan waktu tunggu pendaftaran dengan kepuasan pasien 
di Tempat Pendaftaran Pasien Rawat Jalan (TPPRJ) di Rumah Sakit Grandmed Lubuk Pakam Tahun 2017.

Dari hasil penelitian didapatkan bahwa terdapat sebanyak 7 orang $(13,0 \%)$ responden mengalami waktu tunggu lambat dengan puas pasien hal tersebut dikarenakan pasien tersebut menggunakan pembayaran BPJS PBI (penerima bantuan iuran) sehingga pasien hanya bisa menerima dengan keadaannya. Persepsi pasien terhadap pelayanan yang diberikan tidak hanya dari waktu tunggu tetapi dari sikap perawat terutama perawat tidak memberi informasi tentang peraturan yang ada, perawat tidak memberikan kesempatan bertanya.

Hal tesebut sesuai dengan pendapat Budiastuti (2011) yang menyatakan bahwa memahami kebutuhan dan keinginan konsumen dalam hal ini pasien adalah hal penting yang mempengaruhi kepuasan pasien. Pasien yang puas merupakan aset yang sangat berharga karena apabila pasien puas mereka akan terus melakukan pemakaian terhadap jasa pilihannya, tetapi jika pasien merasa tidak puas mereka akan memberitahukan dua kali lebih hebat kepada orang lain tentang pengalaman buruknya. Untuk menciptakan kepuasan pasien suatu perusahaan atau rumah sakit harus menciptakan dan mengelola suatu system untuk memperoleh pasien yang lebih banyak dan kemampuan untuk mempertahankan pasiennya.

Hasil penelitian ini sejalan dengan penelitian Rachmadi (2010) dengan judul Hubungan Waktu Tunggu Dengan Kepuasan Pasien Rawat Jalan RSUD Kabupaten Karimun yang mengungkapkan bahwa ada hubungan positif yang signifikan antara waktu tunggu dengan kepuasan pasien rawat jalan RSUD Kabupaten Karimun hasil korelasi variabel xy $(r x y)=0,430$ dengan $p<0,05$ yang berarti semakin singkat waktu tunggu pasien maka akan meningkatkan kepuasan pasien umum rawat jalan dan sebaliknya.

Penelitian ini sejalan dengan penelitian yang dilakukan oleh Sarastri (2011) mengenai Faktor-faktor yang mempengaruhi kepuasan pasien di Instalasi Rawat Jalan RSU TUGUREJO Semarang. Hasil penelitian menunjukkan ada hubungan yang bermakna antara faktor waiting time dengan keppuasan pasien rawat jalan (nilai $\mathrm{p}=0,011$ dengan alpha $=0,05$ ). Angka koefiesien korelasi antara faktor waiting time dengan kepuasan pasien yaitu 0,511 dan angka koefiesien korelasi antara faktor waiting time dengan kepuasan pasien sebesar 0,508 .

Penelitian ini sejalan dengan penelitian yang dilakukan oleh Indriany yang berjudul hubungan waiting time dengan kepuasan pasien rawat jalan di Rumah Sakit Cahya Kawaluyan. Berdasarkan penelitian diperoleh $60,2 \% \quad$ responden mengatakan waiting time cepat dan $59,2 \%$ mengatakan puas. Uji chisquare menunjukkan ada hubungan antara waiting time dengan kepuasan pasien rawat jalan, $\mathrm{p}$ value $=0,019$.

Menurut asumsi peneliti bahwa salah satu faktor yang mempengaruhi kepuasaan pasien adalah waktu tunggu pelayanan, jika pelayanan yang diterima oleh pasien cepat maka pasien akan merasa puas, sebaliknya apabila waktu tunggu pelayanan pasien lama maka pasien akan merasa tidak puas dengan pelayanan yang diberikan oleh petugas baik mulai dari 
pendaftaran sampai dengan pelayanan yang ada.

\section{KESIMPULAN}

Berdasarkan hasil uji statistik dan pembahasan tersebut diatas bahwa dapat disimpulkan bahwa hubungan waktu tunggu pendaftaran dengan kepuasan pasien di Tempat Pendaftaran Pasien Rawat Jalan (TPPRJ) di Rumah Sakit Grandmed Lubuk Pakam Tahun 2017:

1. Waktu tunggu pendaftaran pada kategori cepat sebesar 56,5\%.

2. Kepuasan pasien pada kategori puas sebesar 62,1\%).

3. Ada hubungan waktu tunggu pendaftaran dengan kepuasan pasien di Tempat Pendaftaran Pasien Rawat Jalan (TPPRJ) nilai $p(=0,010)<a(=0,05)$.

\section{DAFTAR PUSTAKA}

Aditama, T. Y. (2011). Manajemen Administrasi Rumah Sakit. UI Press.

Assauri, S. (2011). Manajemen Pemasaran (Dasar, Konsep dan Strategi. Jakarta: PT Gramedia Pustaka Utama.

Author. (2008). Standart Pelayanan Minimal Rumah Sakit. Departemen Kesehatan Republik Indonesia.

B., H. (2010). Bukti Empiris Kebijakan Asuransi Kesehatan Sosial: Analisis Survei Aspek Kehidupan Rumah Tangga Indonesia (Sakerti). Jurnal Manajemen Pelayanan Kesehatan, 125.

Budiastuti. (2011). Pelayanan Kesehatan. Yogyakarta: Graha Ilmu.

Demoulin. (2016). Tingkat Kepuasan Pasien Rawat Jalan terhadap Ketepatan Waktu Pelayanan oleh Tenaga Kesehatan di Puskesmas Ranotana Weru, Kecamatan
Wanea, Kota Manado. Fakultas Kedokteran Samratulangi, Manado.

Dewi. (2015). Hubungan Waktu Tunggu Pendaftaran dengan Kepuasan Pasien di Tempat Pendaftaran Pasien Rawat Jalan (TPPRJ) RSUD Sukoharjo . Dinas Kesehatan Sukoharjo.

Febriyanti, D. (2013). Deskripsi Faktor-faktor yang Mempengaruhi Waktu Tunggu Pendaftaran di TPPRJ RSUD Tugurejo, Semarang Universitas Dian Nuswantoro.

Gunarso, S. (2010). Psikologi untuk Membimbing . Jakarta: Gunung Mulia.

Imbalo. (2010). Jaminan Mutu Pelayanan Kesehatan. Jakarta: EGC.

Indarjati. (2010). Kepuasan Pasien. Jakarta: Pranata.

Ismael, S. d. (2014). Dasar-dasar Metodologi Penelitian Klinis. Jakarta: Alfabeta.

N., W. (2010). Analisis Lost Patient di Poliklinik Rawat Jalan Rumah Sakit Pertamina Jaya Tahun 2008. Universitas Indonesia.

Nofiana, d. (2011). Hubungan Mutu Pelayanan Pendaftaran dengan Kepuasan Pasien Rawat Jalan di Rumah Sakit PKU Muhammadiyah, Karanganyar. Jurnal Kesehatan, 106.

Nursalam. (2010). Manajemen Keperawatan. Jakarta.

Rachmadi. (2010). Hubungan Waktu Tunggu dengan Kepuasan Pasien Rawat Jalan RSUD Kabupaten Karimun. Repositori

Robbins. (2012). Perilaku Organisasi: Konsep, Kontroversi dan Aplikasi (Jilid I dan II). Jakarta: Alih Bahasa: Pujaatmaka.

Suryawati. (2011). Kepuasan Pasien Rumah Sakit (Tinjauan Teoritis dan Penerapannya pada Penelitian). Jurnal UNDIP. 
Jurnal Kesehatan Masyarakat \& Gizi, e-ISSN: 2655-0849

Vol. 3 No.2 Edisi November 2020 - April 2021

https://ejournal.medistra.ac.id/index.php/JKG

Received: 29 April 2021 :: Accepted: 30 April 2021 :: Published: 30 April 2021

Taylor S.E, d. (2014). Psikologi Sosial. Jakarta: Kencana Prenada Media Group.

Utami. (2016). Waktu Tunggu Pelayanan Rawat Jalan dengan Tingkat Kepuasan Pasien di RSU Assalam, Gemolong. Ejournal. 